\title{
Farming Gardening Project; Kegiatan Penanaman Nilai- Nilai Karakter Pada Siswa Tunagrahita
}

\author{
Mu'jizatin Fadiana $^{1}$, Djoko Apriono ${ }^{2}$, Heny Sulistyaningrum ${ }^{3}$, Moh \\ Mu'minin ${ }^{4}$ \\ Universitas PGRI Ronggolawe Tuban \\ Email: mujizatin000@gmail.com
}

\begin{abstract}
Mentally retarded students experience obstacles and mental developmental retardation far below average, they experience difficulties in academic, communication and social tasks. Students with moderate and severe mental retardation usually show low socioemotional behavior. They have not yet formed a sense of cooperation, help, sharing, independence, self-confidence and self-control. One of the ways to minimize social emotional behavior is through farming gardening projects. This service program was carried out at SLB C Autism Negeri Tuban targeting mild mentally retarded students $(C)$ and moderate mentally retarded students $(C 1)$. Activities are carried out through the planning, implementation and assessment or evaluation stages. Based on the results of the evaluation, it shows that character values can be grown and developed through a farming gardening project.
\end{abstract}

Keywords: farming gardening project, mental retardation, character values

\begin{abstract}
Abstrak
Siswa tunagrahita mengalami hambatan dan keterbelakangan perkembangan mental jauh di bawah rata-rata, mereka mengalami kesulitan dalam tugas akademik, komunikasi dan sosial. Siswa tunagrahita sedang dan berat biasanya menunjukkan rendahnya perilaku sosial-emosional. Mereka belum terbentuk rasa bekerja sama, tolongmenolong, berbagi, mandiri, percaya diri dan kontrol diri. Rendahnya perilaku sosial emosional dapat diminimalisir salah satunya melalui kegiatan farming gardening project. Program pengabdian ini dilaksanakan di SLB C Autis Negeri Tuban dengan sasaran siswa tunagrahita ringan (C) dan siswa tunagrahita sedang (C1). Kegiatan dilakukan melalui tahap perencanaan, pelaksanaan dan penilaian atau evaluasi. Berdasarkan hasil evaluasi menunjukkan bahwa nilai-nilai karakter dapat ditumbuh kembangkan melalui kegiatan farming gardening project.
\end{abstract}

Kata Kunci: farming gardening project, tunagrahita,nilai-nilai karakter

\section{Pendahuluan}

Setiap warga negara berhak mendapatkan pendidikan, tanpa terkecuali mereka yang menyandang kekurangan atau kelainan, sebagaimana dalam UndangUndang Nomor 20 tahun 2013 tentang Sistem Pendidikan Nasional pada pasal 5 ayat 2 menyatakan bahwa warga negara yang memiliki kelainan fisik, emosional, mental, intelektual maupun sosial berhak mendapat kebutuhan khusus. Berdasarkan undang-undang tersebut dapat dijadikan sebagai dasar yang kuat terhadap pelaksanaan pendidikan bagi anak yang berkebutuhan khusus mendapat 
pendidikan yang layak sebagaimana mereka yang tidak menyandang kelainan. Sehingga diharapkan tidak adanya diskriminasi antara anak berkebutuhan khusus dengan anak yang normal.

Sekolah Luar Biasa (SLB) adalah lembaga pendidikan melayani pendidikan untuk anak-anak berkebutuhan khusus. Salah satu tujuannya adalah mempersiapkan lulusan dengan harapan dapat mandiri ketika hidup dimasyarakat. Salah satu SLB yang ada di Kabupaten Tuban Jawa Timur adalah SLB C Autis Negeri Tuban. Sekolah ini melayani pendidikan dan pembelajaran khusus untuk penyandang tunagrahita dan autis.

Peserta didik tunagrahita mengalami hambatan dan keterbelakangan perkembangan mental jauh di bawah rata-rata, mereka mengalami kesulitan dalam tugas akademik, komunikasi dan sosial (Fadiana \& Citra Dewi Rosalina, 2020). Sering dari mereka bersikap ceroboh dan kurang bisa menempatkan diri mereka, seperti meletakan kaki atau duduk di atas meja, mengganggu proses pembelajaran seperti berteriak di dalam kelas dengan kata-kata yang tidak layak untuk disebutkan, memukul teman dan guru dan perilaku-perilaku menyimpang lainnya. Di samping itu, anak tunagrahita sedang dan berat biasanya menunjukkan rendahnya perilaku sosial-emosional. Hal itu ditunjukkan dengan belum terbentuk rasa bekerja sama, tolong-menolong, berbagi, mandiri, percaya diri dan kontrol diri.

Rendahnya perilaku sosial emosional dapat diminimalisir salah satunya melalui kegiatan farming gardening project. Farming gardening project atau yang sering disebut sebagai kegiatan proyek berkebun adalah kegiatan berkebun yang dilakukan secara berkelompok sebagai wahana dalam menstimulasi perilaku sosial-emosional anak tunagrahita (Ilham, 2018; Khosiah, 2017). Model operasional farming gardening project ini didukung dengan lingkungan sekitar anak, baik lingkungan sekolah maupun lingkungan rumah. Selain lingkungan, bahan-bahan yang digunakan dalam kegiatan farming gardening project adalah bahan-bahan praktis yang digunakan setiap hari oleh orang orang tua di rumah, sehingga kegiatan belajar menjadi menyenangkan karena dilakukan sambil bermain (Diana \& Putri, 2018). Bagi anak tunagrahita bermain sangatlah mengasyikkan, karena mereka tidak mampu duduk berjam-jam dengan tenang dan berlama-lama memusatkan perhatian (Fadiana \& Citra Dewi Rosalina, 2020).

Farming gardening project merupakan kegiatan belajar sekaligus bertindak, di mana anak tunagrahita diberikan kesempatan untuk mengalami penerapan topik dan isi materi yang dipelajari dalam situasi kehidupan sesungguhnya. Belajar berkebun dengan bersumber langsung pada lingkungan alam sekitar akan memberikan pengalaman nyata kepada anak tunagrahita (Fadiana \& Citra Dewi Rosalina, 2020). Dengan melihat dan mengalami secara langsung, bagaimana tanaman tumbuh hingga menghasilkan panen serta memberikan manfaat bagi makhluk hidup lainnya akan membuat mereka peduli dan menghargai lingkungan dengan baik, mandiri, bertanggung jawab, kerja sama, kesalingtergantungan dan ada kemauan untuk melakukan dan bertindak yang pada gilirannya akan menumbuhkan kesadaran untuk memelihara lingkungan.

Proyek berkebun di luar kelas menghadapkan anak tunagrahita pada cara penemuan dan memungkinkan mereka untuk menjadi kreatif dalam bertukar pendapat tentang penemuannya dengan teman sebaya, memiliki keterlibatan yang tinggi dengan pekerjaannya serta memiliki motivasi yang tinggi dalam menyelesaikan pekerjaan. Proyek berkebun secara alami mendorong interaksi diantara sesama anak tunagrahita maupun dengan orang dewasa di sekitar mereka. 
Dengan interaksi ini, maka sikap kerja sama, tolong-menolong, empati, simpati, berbagi (sharing), disiplin dan tanggung jawab dikembangkan. Selain itu, keadaan yang berubah antara indoor dan outdoor memberikan banyak tantangan baru. Dengan tantangan baru yang dihadapkan di luar ruangan, maka sikap percaya diri dan kemandirian anak tunagrahita dikembangkan. Atas dasar pemikiran ini, maka farming gardening project sebagai salah satu metode pembelajaran yang dapat menjadi solusi dalam menangani perilaku sosial-emosional anak tunagrahita dan menjadi sarana untuk menanamkan pendidikan karakter sejak dini .

Pendidikan karakter merupakan pendidikan yang melibatkan penanaman pengetahuan, kecintaan dan penanaman perilaku kebaikan yang menjadi sebuah pola/kebiasaan. Pendidikan karakter tidak lepas dari nilai-nilai dasar yang dipandang baik. Nilai-nilai pendidikan karakter yang dapat ditanamkan pada anak tunarahita, mencakup empat aspek, yaitu: 1) aspek spiritual, 2) aspek personal/kepribadian, 3) aspek sosial, dan 4) aspek lingkungan. Pada pendidikan anak tunagrahita nilai-nilai yang dipandang penting dikenalkan dan diinternalisasikan ke dalam perilaku mereka mencakup: 1) kecintaan terhadap Tuhan YME, 2) kejujuran, 3) disiplin, 4) toleransi dan cinta damai, 5) percaya diri, 6) mandiri, 7) tolong menolong, kerjasama, dan gotong royong, 8) hormat dan sopan santun, 9) tanggung jawab, 10) kerja keras, 11) kepemimpinan dan keadilan, 12) kreatif, 13) rendah hati, 14) peduli lingkungan, 15) cinta bangsa dan tanah air (Putra, 2019).

\section{Metode Pengabdian}

Program pengabdian ini dilaksanakan di SLB C Autis Negeri Tuban, yang beralamat Jalan Dr. Wahidin Sudirohusodo Nomor 867 Kelurahan Sidorejo Kecamatan Tuban Kabupaten Tuban, dengan sasaran siswa tunagrahita ringan (C) dan siswa tunagrahita sedang (C1). Adapun tahapan pengabdian yang akan dilaksanakan adalah sebagai berikut:

1. Tim (Dosen) melakukan diskusi dengan guru dan kepala sekolah SLB C Autis Negeri Tuban tentang materi pelajaran, waktu dan setting kegiatan pengabdian yang akan dilaksanakan.

2. Tim (Dosen) merancang kegiatan Farming Gardening Project (mulai dari perencanaan, kegiatan yang akan dilakukan, dan penggunaan alat dan bahan dan sebagainya). Perancangan kegiatan dikaji dan disesuaikan dengan kebutuhan sekolah mitra berdasarkan hasil diskusi antara tim pengusul dengan mitra.

3. Tim (Dosen dan mitra) menerapkan kegiatan Farming Gardening Project untuk beberapa kali sampai tujuan yang diharapkan bisa terwujud.

4. Tim melakukan observasi, evaluasi dan wawancara kepada mitra untuk mendapatkan data tentang nilai-nilai karakter yang sudah ditanamkan pada siswa tunagrahita di SLB C Autis Negeri Tuban. Dari hasil observasi, evaluasi dan wawancara kemudian dianalisis secara deskriptif kualititatif.

\section{Hasil dan Pembahasan}

Penanaman nilai-nilai karakter yang diberikan melalui kegiatan farming gardening project perlu diciptakan dalam proses penanaman nilai-nilai karakter. Penanaman nilai karakter pada anak tunagrahita bukan hanya sekadar mengharapkan kepatuhan, tetapi harus disadari dan diyakini oleh mereka sehingga mereka merasa bahwa nilai tersebut memang benar dan bermanfaat untuk dirinya 
dan lingkungannya. Untuk membentuk hal demikian, perlu proses, waktu dan kesabaran dari guru maupun orang tua. Proses penanaman nilai-nilai karakter perlu pembiasaan dan tidak instan. Sehingga mereka termotivasi untuk menerapkan dan terus memelihara nilai tersebut dalam kehidupan sehari-harinya. Penerapan pendidikan karakter bagi anak tunagrahita melalui kegiatan farming gardening project dilakukan melalui tahapan-tahapan sebagai berikut:

\section{Perencanaan}

Perencanaan kegiatan farming gardening project dilakukan dengan memperhatikan hal-hal berikut: a) mengenal dan memahami anak tunagrahita seutuhnya sesuai dengan tahapan perkembangan dan karakteristiknya, b) nilainilai pendidikan karakter diterapkan menyatu dengan kegiatan yang dilakukan dengan cara: 1) memilih nilai-nilai karakter yang sesuai dengan kegiatan pembelajaran, dan 2) menentukan indikator perkembangan nilai-nilai karakter, sesuai dengan tahap perkembangan anak, c) menentukan jenis dan tahapan kegiatan yang akan dilaksanakan.

Tim pengabdian masyarakat yang terdiri dari guru dan dosen memberikan informasi atau penjelasan singkat tentang proyek tanaman toga yang akan dilakukan berkenaan dengan prosedur jenis kegiatan. Kegiatan opening dilakukan sebelum anak tunagrahita berada di area berkebun.

Tim pengabdian memberikan kesempatan kepada siswa tunagrahita untuk berpartisipasi dalam memilih tema karakter yang akan dibahas. Dengan partisipasi ini siswa tunagrahita diharapkan menjadi lebih percaya diri. Selain itu, tim dapat mengarahkan siswa tunagrahita pada tema yang akan dibahas pada hari itu, yaitu dengan melakukan tanya jawab berkaitan dengan karakter-karakter positif sekaligus proyek tanaman toga. Pada tahap pemilihan tema, hasil tanya jawab dan diskusi menyepakati bahwa anak-anak akan menanam tanaman toga. Hal ini didasari oleh pemikiran bahwa tanaman toga mudah ditanam dan dipanen dalam waktu yang tidak terlalu lama. Agar mudah dipahami, anak-anak dengan bantuan pendamping dapat membuat pemetaan pikiran tentang karakter yang akan diimplementasikan sekaligus kegiatan proyek berkebun.

Pada tahap ini tim membagi siswa ke dalam beberapa kelompok. Setiap kelompok terdiri dari dua siswa dan mengerjakan tugasnya masing-masing. Selanjutnya siswa bekerja sama, berbagi, dan bergantian untuk menyempurnakan tugas kelompoknya. Dengan bantuan guru pendamping, setiap kelompok merancang kegiatan yang akan dilakukannya.

\section{Pelaksanaan}

Pada tahap pelaksanaan setiap kelompok melakukan pekerjaan sesuai dengan rencana yang sudah disusun sebelumnya. Tim pengabdian bertindak sebagai fasilitator yang siap memberikan bantuan jika diperlukan. Setiap kelompok menyelesaikan pekerjaan sesuai dengan waktu yang telah ditentukan dan memperlihatkan hasil pekerjaannya. Tim mendampingi siswa membantu siswa bila menemukan permasalahan yang dihadapi ketika melakukan kegiatan proyek. Tim mereview apa yang telah dilakukan siswa dengan memberikan pujian kepada siswa.

\section{Penilaian}

Penilaian penanaman nilai-nilai karakter dilakukan melalui kegiatan: 1) pengamatan, yaitu suatu cara untuk mengetahui perkembangan atau perubahan 
sikap dan perilaku anak dalam kehidupan sehari-hari, khususnya selama berada di sekolah dengan cara melihat secara langsung. Untuk mempermudah melakukan pengamatan, pendidik menggunakan instrumen pengamatan dalam bentuk check list $(\sqrt{ }), 2$ ) unjuk kerja, merupakan penilaian yang dilakukan dengan mengamati kegiatan anak melakukan sesuatu dalam menerapkan nilai-nilai karakter, 3) pencatatan anekdot (anecdotal record), yaitu menggambarkan peristiwa-peristiwa penting atau unik yang terjadi sehari-hari, 4) percakapan atau dialog, yaitu menanyakan kepada anak secara langsung tentang kegiatan farming gardening project. Pendidik mewancarai anak-anak ketika beraktivitas dengan melontarkan pertanyaan secara spontan. Simpulan hasil wawancara digunakan pendidik untuk memberikan nilai pada anak didik.

\section{Simpulan}

Perencanaan pendidikan karakter melalui farming gardening project di SLB C Autis Negeri Tuban dilakukan tim pengabdian dengan beberapa tahapan dari persiapan mengenai prosedur kegiatan proyek, pengkondisian kelompok anak tunagrahita hingga membuat mind maping bersama mereka. Mind maping diperlukan untuk acuan dalam mengimplementasikan pendidikan karakter ke dalam kegiatan proyek berkebun. Pelaksanaan nilai-nilai karakter melalui farming gardening project dilakukan tim pengabdian dengan kegiatan mengamati, berdialog untuk menumbuhkan rasa empati dan peduli serta mempraktekkan langsung hasil dari dialog dalam kegiatan. Penilaian dilakukan dengan cara pengamatan, unjuk kerja, pencatatan, dan percakapan atau dialog ketika mereka melakukan proyek berkebun. Hasil dari penilaian menunjukkan bahwa nilai-nilai karakter dapat ditumbuh kembangkan melalui kegiatan farming gardening project.

\section{Daftar Pustaka}

Diana, D., \& Putri, Y. (2018). Penerapan Metode Farming Gardening Project Dalam Meningkatkan Perkembangan Kognitif Anak Usia Dini Di Paud Laboratorium Model Universitas Muhammmadiyah Pontianak. Pena Kreatif: Jurnal Pendidikan. https://doi.org/10.29406/jpk.v7i2.1395

Fadiana, M., \& Citra Dewi Rosalina. (2020). Peningkatan Rasa Percaya Diri Siswa Tunagrahita Melalui Pembelajaran Terintegrasi Semiotik Dengan Media Buku Pop Up. Dinamisia: Jurnal Pengabdian Kepada Masyarakat. https://doi.org/10.31849/dinamisia.v4i2.3940

Ilham, I. (2018). Pengaruh Metode Farming Gardening Project Sebagai Solusi Pembelajaran Alam Di TK Kuncup Bahari Kendari. Jurnal Smart Paud. https://doi.org/10.36709/jspaud.v1i1.3519

Khosiah, S. (2017). Implementasi Pendidikan Karakter Melalui Farming Gardening Project Pada Anak Usia Taman Kanak-Kanak. Fikrah : Journal of Islamic Education. https://doi.org/10.32507/fikrah.v1i2.241

Putra, G. D. (2019). Studi Deskriptif Penerapan Pendidikan Karakter Anak Tunagrahita Sedang Di Sekolah Dasar Luar Biasa. Dinamika Jurnal Ilmiah Pendidikan Dasar. https://doi.org/10.30595/dinamika.v10i1.3881 
Farming Gardening Project; Kegiatan Penanaman Nilai-Nilai Karakter Pada Siswa Tunagrahita

Mu'jizatin Fadiana, Djoko Apriono, Heny Sulistyaningrum, Moh Mu'minin 